\title{
CORPORATE GOVERNANCE, FIRM PERFORMANCE, AND ECONOMIC GROWTH - THEORETICAL ANALYSIS
}

\author{
Marinko ŠKARE ${ }^{1}$, Tea HASIĆ ${ }^{2}$ \\ ${ }^{1,2}$ Faculty of Economics and Tourism, Juraj Dobrila University of Pula, \\ Zagrebačka 30, 52100 Pula, Croatia \\ E-mails: ${ }^{1}$ mskare@unipu.hr (corresponding author); ${ }^{2}$ thasic@unipu.hr
}

Received 11 March 2015; accepted 07 July 2015

\begin{abstract}
Corporate governance in today's modern economies is growing in importance within the growth accounting equation. Although we look at corporate governance as final product of 20/21 $1^{\text {st }}$ century economies, old economic growth theories were aware of its importance for growth and development. Roots of corporate governance go back to the ancient economies of India and Greece also. This paper offers a consistent literature review assessing the nexus between corporate performance and economic growth. Individual and cross-country studies show corporate governance in majority of the cases positively affects firms performance and in turn nations' economic growth. Empirical and theoretical research show corporate governance is an important growth determinant to be reviewed in the field of growth models. This article summarizes main findings providing future research directions on the corporate governance economic growth nexus.
\end{abstract}

Keywords: corporate governance, economic growth, sustainability, firm performance, Gov-score, efficiency, capital, stakeholders, shareholders.

JEL Classification: G30, G38, M14, O16.

\section{Introduction}

"In its broadest sense, corporate governance is concerned with holding the balance between economic and social goals and between individual and communal goals. The governance framework is there to encourage the efficient use of resources and equally to require accountability for the stewards of those resources. The aim is to align as nearly as possible the interest of individuals, of corporations, and of society. The incentive to corporations and to those who own and manage them to adopt internationally accepted governance standards is that these standards will assist them to achieve their aims to attract investment. The incentive for their adoption by states is that these standards will strengthen their economies and encourage business probity" (Claessens 2006: 94).

"The objective of a good corporate governance framework would be to maximize the contribution of firms to the overall economy - that is, including all stakeholders. Under this definition, corporate governance would include the relationship between 
shareholders, creditors, and corporations; between financial markets, institutions, and corporations; and between employees and corporations" (Claessens 2006: 94).

There is a vast body of economic and legal literature where the concept of corporate governance is (attempted to be) defined. Definitions are similar, but still, they differ. For instance, MacMillan and Downing (1999), as cited in Gokhan Gunay (2008: 1) define corporate governance as a system by which companies are directed and controlled to produce high financial performance, whilst Letza et al. (2004) as cited in Gokhan Gunay (2008: 2) emphasize that corporate governance is about institutional arrangements for relationship among various economic actors, who may have direct or indirect interests in corporation. Both definitions are correct, but the difference arises from the author's point of view. First definition is "shareholder - oriented" while second (broader) definition is "stakeholder - oriented".

Namely, corporate governance scholars are (generally) "pro shareholders" or "pro stakeholders" oriented, and consequently they stand for shareholders or stakeholders governance model (Gangone, Ganescu 2014).

Countries with better corporate governance achieve higher income growth rates, same as countries with a larger share of socially responsible firms (Škare, Golja 2014). Measuring corporate governance impact on the firm's performance and in turn economic growth is subject to noteworthy methodological limitations. Cross-country studies show the link between corporate governance and financial performance is highly biased. Using different indicators (scores) for corporate governance results in mixed (positive/ negative) impacts on firm's financial performances. In this article such methodological limitations are addressed providing guidelines and future directions for measuring corporate governance impact on economic growth. Using Tobin's Q, capital expenditures, REO, net profit margin, net sales growth, ROA as proxy for corporate governance show diverse empirical links to firms' performances. Ownership structure and dominant control rights have deep impact on innovation dynamics and thus economic growth.

This paper is structured as follows. Introduction offers summary on corporate governance importance and state of research. Section 1 explains the concept of corporate governance while section 2 tries to depict the framework for an efficient corporate governance system. Section 3 offers theoretical and empirical findings on the possible link that exists between corporate governance and firms' performances. Summary of the empirical findings on this link is presented in section 4. Section 5 reviews state of theoretical and empirical findings explaining the impact of corporate governance on economic growth. Future guidelines and directions to follow for future corporate governance - growth studies is discussed in the conclusions.

\section{The concept of corporate governance}

According to Shareholders' governance model (Demsetz 1983; Fama 1980; Jensen, Meckling 1976), only the interest of shareholders should be considered in the governance of the corporation. Shareholders are regarded as owners of their shares and co-owners of the company. Thus, directors are considered as their agents - obliged to 
maximize their principals' profit. Moreover, according to Fama and Jansen (1983) as cited in Gokhan Gunay (2008: 8), shareholders are the residual claimants who bear economic risk, and therefore the value of their shares should be maximized (see Agrawal, Knoeber 2012).

According to Stakeholders' governance model (Clarke 1998; Mills, Weinstein 2000; Post et al. 2002), the interest of all stakeholders should be considered in the governance of corporations. Blair (1998) emphasizes that shareholders are not the only residual claimants or risk bearers, because other stakeholders such as employees (Penger, Černe 2014) make firm-specific investment, i.e., specificity (Gokhan Gunay 2008). Moreover, Plender (1998) points out that for modern Anglo-Saxon corporations there is no sense in understanding shareholders as residual risk takers. That is because financial institutions own most of the company shares, and these institutions diversify their risk (Gokhan Gunay 2008).

In Anglo-Saxon countries, the structure of shareholders is usually dispersed. Shareholders are "weak" and unable to control firm managers who control the company. It was Adam Smith (1776) who first had noticed that:

"The directors of such (joint-stock) companies, however, being the managers rather of other people's money than of their own, it cannot well be expected, that they should watch over it with the same anxious vigilance with which the partners in a private copartnery frequently watch over their own. Like the stewards of a rich man, they are apt to consider attention to small matters as not for their master's honor, and very easily give themselves a dispensation from having it. Negligence and profusion, therefore, must always prevail, more or less, in the management of the affairs of such a company." - as cited in Jensen and Meckling (1976).

This problem was lately described as principal-agent problem (or agency problem). Agency theory, introduced by Jensen and Meckling (1976), attempts to reduce agency problem (in economic terminology) or to decrease the conflict of interest between different groups involved in corporate governance (in legal terminology). Thus, it advises companies to implement the system of corporate governance that induces directors to act in their principals' best interest (Maurović, Hasić 2014).

In Continental European countries the shareholders' structure is traditionally concentrated, what means that one (or several shareholders who act in concern) have control over the company, as they control decision making process in general meetings of shareholders and on board level - as they can impact on directors. In this kind of companies, the agency problem between shareholders and directors does not exist (or it is negligible), but regularly there is a divergence between the controlling and non-controlling shareholder's interest. In economic theory, it is known as second-leveled agency problem (Davies 2000; Armour et al. 2009).

It is in Continental-European Company Law legal doctrine where for the first time was emphasized that joint-stock company is a person with its interests (Schmidt 1997). Accordingly, as a person, it may not be owned by someone else (neither by the natural person nor a legal entity). Shareholders are only the members of the company. They 
hold shares, and consequently they have certain governing rights - the most important is the right to exercise their vote at general meeting of shareholders, but shareholders should not be considered as owners of the company, and, therefore, they do not have any property right in the enterprise (see Croatian Constitutional Court, Case U-I-4120/2003). Directors are agents of the company, what means that company is their principal (AktG par. 78/1; Croatian Companies Act, par. 241/1). Accordingly, directors are obliged to run a business in the best interest of the company as a whole, not just in the shareholders' interest (Cahn, Donald 2010). The letter approach is logical if we bear in mind that in Continental-European countries the shareholders' structure is traditionally extremely concentrated, so identifying company's interest with shareholders' interest would practically mean identification with controlling shareholder's personal interests - what would be extremely discriminating for minority shareholders and the mere essence of coshareholdership would be denied.

In Continental-European countries the doctrine of "company's best interest" have gone so far that even shareholders are obliged to exercise their votes in the best interest of the company as a whole, instead in their personal interest (see Cases Linotype 1988, BGHZ 103, 184 and Girmes 1995, BGHZ 129, 136 as cited in Pistor and Chenggang (2002: 33-34).

Even in Anglo-Saxon countries directors owe so-called fiduciary duties (of care and loyalty) vis-à-vis the company (see: Companies Act 2006, par. 170/1). Therefore, directors are obliged to take decisions in the best interest of the company as a whole, not in the best interest of shareholders. It means that directors have to take care of long-term interest of the company (Companies Act 2006, par. 172/1).

After a brief overview of corporate governance definition development, we may conclude that defining corporate governance exclusively as a tool for shareholders' profit increase seems to be obsolete. Namely, every company which intends to have easily access to capital (either equity or debt capital), which intends to employ "first class" employees in an attempt to produce "first class" products or to offer the best quality services etc., is compelled to implement "the best practice of corporate governance" in their governance system, and the best practice of corporate governance always "bears in mind" interests of vast spectrum of stakeholders. All relevant stock-exchange markets have issued their Codes of Corporate Governance and only corporations that have implemented the governance practice recommended by those codes are listed on the stock exchange lists. The latter statement is not entirely correct. Namely, Codes of Corporate Governance are not binding instruments; they function on so-called "comply or explain system" that was first introduced in UK by Cadbury's Code (1992). Accordingly, corporations that haven't implemented the best governance practice recommended by the code may be listed on the stock-exchange only if they manage to explain why they have chosen not to apply the code's recommendation. Nevertheless, by explaining that they haven't implemented codes' recommendations, corporations indirectly admit that they are not desirable to invest in. If we bear in mind that corporations that want to be listed on stock exchanges are those that want to attract new investors, the logical consequence is that the number of listed companies that have decided not to implement the best corporate governance practice is extremely low. 
The purpose of "The best CG practice implementation" is to ensure that (all) stakeholders are satisfied with the governance and to achieve long-term sustainability for the company. On the other hand, to be a member of a long-term profitable company is the "final goal" of every shareholder (excluding punters, who only look for a short time profit). Therefore, we may conclude that different definitions of corporate governance do not exclude each other. In contrary, they supplement each other. Namely, all abovementioned definitions of corporate governance may be resumed in OECD's definition of corporate governance (OECD 2004: 11): "Corporate governance involves a set of relationship between a company's management, its board, its shareholders and other stakeholders. Corporate governance also provides the structure through which the objective of the company are set, and the means of attending those objectives and monitoring performance are determined. Good corporate governance should provide proper incentives for the board and management to pursue objectives that are in the interest of the company and its shareholders and should facilitate effective monitoring." However, the latter definition seems to be complete only if we add a following OECD's statement (OECD 2004: 3): "In today's economies, interest in corporate governance goes beyond that of shareholders in the performance of individual company. As businesses play a pivotal role in one country's economy, good corporate governance is a significant segment of economic growth."

\section{Appropriate system of corporate governance}

As definitions of corporate governance differ, the corporate governance systems vary too, not only across countries but firms and industry sectors too. There is no "one fit" model of corporate governance, therefore each country should develop a spectrum of mechanisms aimed to prevail the agency problem either on first (directors vs. shareholders), second (minority vs. majority shareholders) or third level (company vs. stakeholders).

The role of corporate governance system is to reduce or overcome the conflict of interest that in a particular company exist and thus to reduce the agency costs (see Mijoč et al. 2014). Which system of corporate governance is going to be applied depends on shareholders who establish the company (so called founders of the business) as they decide, under the "articles of association", what kind of governance will be applied. In their decision founders are limited by the legal framework. Most scholars recognize two regularly used systems of corporate governance: one-tier and a two-tier system. Onetier system is traditionally used in Anglo-Saxon countries where vast majority of companies have dispersed structure of shareholders. Two-tier system traditionally dominates in Continental-European countries where structure of shareholders is traditionally concentrated. Nevertheless, in most European countries (Croatia, France, Italy, Slovenia, FYR Macedonia, Iceland, Lithuania, Netherlands, Portugal) it is possible to choose between one-tier and two-tier system of corporate governance and the choice is conferred upon the founders of the company. It is worthy to notify that one-tier and a two-tier system of corporate governance are not the only models of corporate governance ${ }^{1}$. They should

\footnotetext{
${ }^{1}$ Specific models exist in Sweeden, Switzerland, across Asian countries, etc.
} 
be taken as a "skeleton" because they only regulate whether the company is going to be governed by general meeting, the supervisory board and board of directors or general meeting and the board. For instance, two companies who implemented one-tier system may be governed by drastically different system of corporate governance: company " $A$ " is obliged to disclose every decision taken on the board of directors on company's website and one-third of non-executive directors must be employee's representatives, whilst in company " $B$ " board's decision do not have to be announced on company's website, neither employees are entitled to have their representatives on the board.

Therefore, each company should implement the system of corporate governance that is appropriate to combat those conflict(s) of iinterest that present the threat to company's best interest. As it was mentioned before, in implementing the system of corporate governance, founders are limited by the legislative framework (usually set by Companies Act and Codes of Corporate Governance). Those limitations prevent founders to establish the system of governance that is adequate to achieve their personal interest instead the interest of the company as a whole.

\section{Corporate governance and firm performance - theoretical analysis}

In this chapter, the purpose is to discuss following thesis (without referring on empirical evidences): If the company applies best corporate governance practice, effects on firm performance are multiple.

According to IFC (International Finance Corporation) ${ }^{2}$, good corporate governance facilitates access to capital (equity and debt capital) what consequently provides longterm competitiveness for the company. Namely, businesses that actively promote good corporate governance practice and that apply highest governance standards, tend to attract more investors willing to provide capital at a lower cost, as a risk inherent to share investment is maximally reduced (IFC 2011).

According to (Ehikioya 2009), a well-defined and functioning corporate system helps a firm to attract investment, raise funds, and strengthen the foundation for firm performance. Moreover, good corporate governance shields a firm from vulnerability to future financial distress.

Shleifer and Vishny (1997) suggest that effective corporate governance minimizes controlling-shareholders' impact on managers, what consequently increase the probability that managers will invest in positive net present value projects for the firm gain.

In order to discuss in detail the possible effects of sound corporate governance on firm performance, we separately yield several assumptions regarding the influence of good corporate governance on: reducing agency costs, easier access to capital (both equity and debt) and better reputation.

\footnotetext{
${ }^{2}$ IFC is a member of the World Bank Group. It is the largest global development institution focused exclusively on the private sector in developing countries (see more at: www.ifc.org).
} 


\subsection{Reducing agency costs and enhancing business efficiency}

Compliance with the standards of good corporate governance reduces the conflict of interest between different stakeholders who participate in governance, consequently reducing the agency costs. Responsible governance (consisted of effective risk management and internal controls) enables recognition of potential problems before the serious threat occurs, and consequently it creates preconditions for the long-term development of the company (IFC 2011). Moreover, compliance with the standards of good corporate governance helps to enhance the decision-making process. For example, directors and shareholders are expected to make more quality decisions when they are better informed, when communication process is regulated in an efficient manner and when company's governance structure allows them to understand their roles and responsibilities clearly. That, in turn, should significantly increase the efficiency of financial and business activity of the company (IFC 2011).

\subsection{Easier access to equity capital}

Well-governed companies are suitable for investors. Good corporate governance is based on principles of accountability, efficiency, fairness and responsibility in the management of the firm, transparency - including completeness and accuracy of the information at all levels. The principle of transparency is of particular importance for investors because it provides insight into business and financial data on the company before share acquisition.

According to McKinsey \& Company (2000) as cited in IFC (2011), there is an attempt amongst investors to introduce corporate governance practice as an essential criterion when making investment decisions, what seems to be of significant importance. Apparently investors have recognized that the better corporate governance is, resources are more likely to be used in their interest and the risk of channelizing them to private portfolios is minimalized.

The good corporate governance practice has a particular significance in emerging markets, where investors are not protected as they are in developed markets. Namely, the investment risk is bigger and accordingly, the capital cost is higher in countries or regions where political situation is turbulent or where legal framework or its judicial enforcement is not enough developed to guarantee protection to investors. Thus, even modest improvements in corporate governance, in relation to other companies, can attract investors and reduce the price of equity capital, what makes the company more competitive (ICF 2011). According to McKinsey \& Company (2000), a significant percentage of investors are willing to ensure an extra payment for well-governed company. For example, they are prepared to pay $13 \%$ more for well-governed company in Germany or $14 \%$ for well-governed company in USA, whilst they are prepared to pay $25 \%$ more in China and even 38\% more in Russia (cited in IFC 2011).

Moreover, companies that want to have access to domestic and international capital markets will have to comply with the prescribed standards of corporate governance. According to OECD's Principles of Corporate Governance (2004: 13): "The degree to which corporations observe basic principles of good corporate governance is an increasingly 
important factor in investment decisions. Of particular relevance is the relation between corporate governance practices and the increasingly international character of investment. International flows of capital enable companies to access financing from a much larger pool of investors. If countries are to reap the full benefits of the global capital market, and if they are to attract long-term "patient" capital, corporate governance arrangements must be credible, well understood across borders and adhere to internationally accepted principles. Even if corporations do not rely primarily on foreign sources of capital, adherence to good corporate governance practices will help improve the confidence of domestic investors, reduce the cost of capital, underpin the proper functioning of financial markets, and ultimately induce more stable source of financing."

\subsection{Easier access to debt capital}

Companies that have implemented high standards of corporate governance, regularly provide the necessary capital for running a business for lower cost. The cost of the capital depends on the level of risk that investors take when supply company with the capital: the higher the risk, the higher the cost of the capital (IFC 2011). The risk involves the jeopardy of violating the investors' right. Thus, if the rights of investors are adequately protected, the price of equity and debt capital can be reduced (IFC 2011).

It should be noted that there is an attempt amongst investors who provide debt capital, i.e. creditors, to include corporate governance practice as an important criterion ${ }^{3}$ when making investment decisions. Therefore, implementation of good corporate governance enables company to pay lower interest rates and to receive longer deadlines for loans repayment (IFC 2011).

\subsection{Better reputation}

Good corporate governance practice contributes to a better reputation of a company. Public confidence in the company is likely to ensure greater confidence in company's products (or services) what consequently provides greater profit. Moreover, as it is explicitly emphasized in IFC (2011), good reputation and company's goodwill ${ }^{4}$ often play a significant role in the assessment of the company's value, what seems to be of primary importance when company is obliged to provide appropriate credit guarantee.

\section{Corporate governance and firm performance - empirical evidence from literature review}

Numerous empirical studies, mentioned in the vast body of literature, attempt to evaluate the relationship between corporate governance and firm performance. In that order, firm performance is (regularly) measured by operating performance, valuation, and stock returns while there is a range variation of measurements attempted to evaluate good corporate governance.

\footnotetext{
${ }^{3}$ For instance: a transparent ownership structure and adequate financial reporting.

4 "Goodwill, in accounting terms, presents the exceeding on the fair value price of the company's assets that is being purchased. Or to simplify, goodwill is an addition on price that a company has to pay when buying another company" (IFC 2011:18).
} 
According to Love (2011: 48), there are three primary data sources used by researchers to construct the measure of corporate governance quality:

1. Information from company's by-laws and articles of association,

2. Independent rankings constructed by rating agencies, such as Standard \& Poor's, and

3. Firms' surveys.

Each of these data (from source "1" to source "3") has its pros and cons. For instance, information from company's by-laws and articles of association suffers from the lack of evidence that measures prescribed by by-laws and articles of association are implemented. The independent rankings lack reliability, as the expert's opinion (used to measure corporate governance) depends on the quality of the expert - that is not observable. Finally rankings built on firms' surveys may suffer from firms' incentives to misreport the quality of their governance (Love 2011). Therefore, a combination of data from sources reduces imperfections of each source. In numerous empirical studies where correlation between corporate governance and firm performance is evaluated, corporate governance is measured by a corporate governance index. Different researchers have settled separate indexes. For instance, Gompers et al. (2003) have constructed a corporate governance index "G" which is consisted of 24 factors divided into five groups: tactics for delaying hostile bidders, voting rights, director protection, other takeover defense and state laws. Bebchuk et al. (2004) have introduced two indexes, so called "entrenchment index" (or "E" index) which is built on 6 factors and "the other provisions index" (or " $\mathrm{O}$ " index) which is made on 18 factors including " $\mathrm{E}$ " index. Brown and Caylor (2004) have introduced so-called "governance index" (or Gov-Score index) constructed on 51 elements divided into eight categories: audit, board of directors, charter/by-laws, director education, executive and director compensation, ownership, progressive practice, and state of incorporation (see Gawer 2012). In forthcoming empirical research where correlation between corporate governance and firm performance in Croatian companies listed on Croatian (Zagreb) stock-exchange is going to be tested, we intend to create an index using Gov-Score index as an role model, since it is built on 51 factors and we are assured that the most reliable indexes are those consisted of numerous factors. Similar research can be found in (Korent et al. 2014).

Vast majority of empirical studies attempted to evaluate the relationship between corporate governance and firm performance declare firm performance is measured by operating performance, valuation, and stock returns.

$\mathrm{ROE}^{5}$ and profit margin ${ }^{6}$ usually assess operating performance, Tobin's $\mathrm{Q}$ is regularly used to measure valuation while dividend yield is used to measure stock return.

\footnotetext{
${ }^{5}$ Return on equity (ROE) measures the rate of return on the ownership interest (shareholders' equity) of the common stock owners. It measures a firm's efficiency at generating profits from every unit of shareholders' equity (also known as net assets or assets minus liabilities). ROE shows how well a company uses investment funds to generate earnings growth. ROEs between $15 \%$ and $20 \%$ are generally considered good.

${ }^{6}$ Profit margin is a measure of profitability. It is calculated by finding the net profit as a percentage of the revenue.
} 
Although the vast majority of studies suggest that there is a positive correlation between corporate governance and firm performance, some studies do not confirm that result. Instead, they suggest that the correlation between corporate governance and firm performance is negative or neutral, i.e. it does not exist at all. Several studies question the causality of this relationship, and thus they suggest that it is a firm performance that positively affects corporate governance, not vice versa. Most empirical studies are done for one country, usually for USA or UK where capital market is developed, and shareholder structure dispersed. Nevertheless, in recent years similar researches have been done in developing and undeveloped countries, and there are several cross-country studies, too.

According to Love (2011), we deliver (in Table 1) the list of studies that suggest positive, negative or neutral relation between corporate governance and firm performance and those that question the nature of causality of that relationship. Studies are divided into following categories: studies done for USA; for other countries; cross-country studies. The list is incomplete, but it suggests that studies evaluating correlation between corporate governance and firm performance are numerous, and their results are divergent. Nevertheless, the thesis that corporate governance positively affects firm performance still prevails.

\section{Effects on economic growth}

In the broadest sense, well-governed companies contribute more to the economic growth, as those companies are stable, sustainable and capable to provide regular profit to their shareholders and regular earnings to their employees, and to strengthen investors' confidence in the capital market.

If we consider that OECD - Organisation for Economic Co-operation and Development, which is entitled to promote policies designed to achieve the highest sustainable economic growth and standard of living in member countries and thus to contribute to the development of the world economy, has issued "The OECD Principles of Corporate Governance" as one of 12 key standards for sound financial system, it is undisputable that corporate governance affects positively on economic growth.

According to OECD (2004: 3), companies play a pivotal role in one country's economy, thus good corporate governance is a significant segment of economic growth. Moreover, corporate governance is one key element in improving economic efficiency and growth as well as enhancing investors' confidence (OECD 2004: 11). Namely, the presence of an effective corporate governance system, within an individual company and across an economy as a whole, helps to provide a degree of confidence that is necessary for the proper functioning of market economy. As a result, the cost of capital is lower, and firms are encouraged to use resources more efficiently, thereby underpinning economic growth (OECD 2004: 11).

According to Claessens (2006: 8), the research on the role of corporate governance for economic growth is best understood from broader perspective. For instance, the importance of the financial system for economic growth has been clearly established by 
Table 1. Studies evaluating correlation between corporate governance and firm performance

\begin{tabular}{|c|c|}
\hline $\begin{array}{c}\text { Corporate governance affects positively on firm } \\
\text { performance }\end{array}$ & $\begin{array}{l}\text { There is no positive relationship } \\
\text { between corporate governance, and firm } \\
\text { performance / Firm performance affects } \\
\text { positively on corporate governance }\end{array}$ \\
\hline I. USA & I. USA \\
\hline $\begin{array}{l}\text { 1. Gompers et al. (2003) } \\
\text { 2. Bebchuk et al. (2004) } \\
\text { 3. Brown, Caylor }(2004) \\
\text { 4. Larcker et al. (2007) }\end{array}$ & $\begin{array}{l}\text { 1. Yen (2005) } \\
\text { 2. Core et al. (2006) } \\
\text { 3. Ferreira, Laux (2007) } \\
\text { 4. Lehn et al. (2006) } \\
\text { 6. Chidambaran et al. (2008) } \\
\text { 7. Gillan et al. (2006) }\end{array}$ \\
\hline II. OTHER COUNTRIES & II. OTHER COUNTRIES \\
\hline $\begin{array}{l}\text { 1. Chong, Lopez-de-Silanez (2007) - Argentina, } \\
\text { Brazil, Chile, Colombia, Mexico and } \\
\text { Venezuela } \\
\text { 2. Nenova (2005) - Brazil } \\
\text { 3. Abdul Wahab et al. (2007), Haniffa, Hudaib } \\
\text { (2006) - Malaysia } \\
\text { 4. Toudas, Karathanassis (2007) - Greece } \\
\text { 5. Gruszczynski (2006), Kowalewski et al. } \\
\text { (2007) - Poland } \\
\text { 6. El Mehdi (2007) - Tunisia } \\
\text { 7. Black (2001) - Russia } \\
\text { 8. Bae et al. }(2007) \text { - Korea } \\
\text { 9. Zheka (2006) - Ukraine } \\
\text { 10. Kyereboah - Coleman (2007) - Africa } \\
\text { 11. Reddy et al. }(2008)-\text { New Zeland } \\
\text { 12. Bortolotti, Belratti (2006) - China } \\
\text { 13. Erickson et al. }(2005) \text { - Canada } \\
\text { 14. Atanasov et al. }(2007) \text { - Bulgaria } \\
\text { 15. Black, Khanna (2007) - India }\end{array}$ & $\begin{array}{l}\text { 1. Pham et al. (2007) - Australia } \\
\text { 2. Rui et al. (2002) - China } \\
\text { 3. Aman, Nguyen (2007) - Japan }\end{array}$ \\
\hline III. CROSS-COUNTRY STUDIES & III. CROSS-COUNTRY STUDIES \\
\hline $\begin{array}{l}\text { 1. Klapper, Love (2004) } \\
\text { 2. Durnev, Kim (2005) } \\
\text { 3. Bauer et al. }(2003) \\
\text { 4. Baker et al. }(2007) \\
\text { 5. Aggarwal et al. }(2007) \\
\text { 6. Chhaochharia, Laeven (2007) } \\
\text { 7. De Nicolo et al. }(2008) \\
\text { 8. Doidge (2007) } \\
\text { 9. Durnev, Fauver (2007) } \\
\text { 10. Bruno, Claessens (2007) }\end{array}$ & \\
\hline
\end{tabular}

Source: Author adaptation from Love (2011); Corporate governance and performance around the world: what we know and what we don't, 63-64. 
Levine (1997) and World Bank (2001) - as cited in Claessens (2006: 8). They suggest that almost regardless of how financial development is measured, there is a positive relation between financial development and the level of GDP per capita growth. In order to function well, financial institutions are required to implement good corporate governance practice, thus good corporate governance positively affects financial institutions' and financial markets' performance, consequently leveraging economic growth. Corporate governance has large impact on economic growth. Aghion et al. (1999) provide a key insight while Levine (1997) determines the link between capital markets efficiency and growth. The problem of capital governance (economic entrenchment) as defined in Morck et al. (2005) has deep impact on economic growth through resource misallocation resulting in X-inefficient firms (Leibenstein 1966).

\section{Conclusions}

Corporate governance is an important channel not only in achieving economic growth but also distributing the beneficial effects of growth throughout the society. All started with Schumpeter's creative destruction theory and his view on corporate institutions and new firms as vital for technological development (Baležentis, Balkienè 2014). Despite a vast body of literature on the subject this nexus is not even near to be unravel. Although a majority of studies speak in favour of corporate governance impact on firms' performance, and thus economic growth, economic theory stands silent. Schumpeter was right; capitalism is a changing process, always in a state of flux. The same holds true for firms and corporate governance. It is in reality the level of the corporate governance that ranks firms as new or old and ready for commission by the creative destruction forces. Within this same evolutionary idea of firms and growth as pointed out by Schumpeter lies the biggest problem of capitalism, thus, corporation. Since growth is a process of change, pinpointing sound, standard corporate governance principles limit business to adapt to change. Not all business can adapt to change and we know that for a fact. What it is that differentiate firms in two groups; ones that can and ones that cannot adapt to change? The conclusion follows a logic developed by Schumpeter. Accepting that growth is a dynamic process under constant change, firms' must also be dynamic and continuously change their organizational structures. However, if we design firms' as "fortresses" built on sound corporate governance policies issued by OECD in 2004 or 2012 how can a "fortress" adapt to changes in 2015? Obviously, it cannot and it will be replaced by something new, not so powerful but dynamic and adaptable to change. This is the point authors tried to match in this study and encourage further studies using this article as reference point. Flexible and dynamic corporate governance demands much more than sound governance policies or standards. Looking at firms from the tangible point of view put in the second row the true nature of change - intangible assets and values within the firms. Vision, employees' appreciation, risk awareness, social responsibilities are the true factors qualifying businesses as new and not old for commission. To draw an ideal corporate governance charter both tangible and intangible firms values (Verbič, Polanec 2014) have to be considered. 
This paper offer a summary on theoretical and empirical findings of previous research explaining the link between corporate governance and firms' performances and thus country's economic growth. Guidelines and future directions for research on corporate governance - economic growth link have been reviewed here. Main limitation of the paper is that a new methodological framework designed to search the nexus between corporate governance and economic growth is missing. Future research should concentrate on the best proxy identification for corporate governance. Causality between corporate governance and economic growth require a non-biased indicator for corporate governance measurement. Otherwise, explaining how corporate governance affects economic growth becomes cumbersome since the connection to capital markets, inequality, and wage distribution, X-efficiency issues.

\section{Funding}

This work has been fully supported by the Croatian Science Foundation [under the project number 948] - "Modelling Economic Growth - Advanced Sequencing and Forecasting Algorithm". Any opinions, findings, and conclusions or recommendations expressed in this material are those of the author(s) and do not necessarily reflect the views of Croatian Science Foundation.

\section{Disclosure statement}

Authors do not have any competing financial, professional, or personal interests from other parties.

\section{References}

Abdul Wahab, E. A., et al. 2007. The impact of the Malaysian code on corporate governance: compliance, institutional investors and stock performance, Journal of Contemporary Accounting \& Economics 3(2): 106-129. http://dx.doi.org/10.1016/S1815-5669(10)70025-4

Aghion, P.; Caroli, E.; Garcia-Penalosa, C. 1999. Inequality and economic growth: the perspective of the new growth theories, Journal of Economic Literature 37(4): 1615-1660.

http://dx.doi.org/10.1257/jel.37.4.1615

Aggarwal, R., et al. 2007. Do U.S. firms have the best corporate Governance? A cross-country examination of the relation between corporate governance and shareholder wealth, Working Paper 2006-03006. Fisher College of Business, Ohio State University.

Agrawal, A.; Knoeber, Ch. R. 2012. Corporate governance and firm performance, Chapter 26 in R. T. Christopher, W. F. Shughart (Eds.). Managerial economics. New York, NY: Oxford University Press.

Aman, H.; Nguyen, P. 2007. Do stock prices reflect the corporate governance quality of Japanese firms? [online] University of New South Wales. Available from Internet: http://papers.ssrn. com/sol3/ papers.cfm?abstract_id $=983301$

Armour, J.; Hansmann, H.; Kraakman, R. 2009. Agency problems, legal strategies and enforcement, Discussion Paper No. 644 [online]. John M. Olin Center for Laws, Economics and Business, Harvard. Available from Internet: http:/www.law.harvard.edu/programs/olin_center/

Atanasov, V., et al. 2007. How does law affect finance? An examination of financial tunneling in an emerging market, Finance Working Paper 123/2006. ECGI. 
Bae, K.-H., et al. 2007. Do controlling shareholders' expropriation incentives imply a link between corporate governance and firm value? Evidence from the aftermath of Korean financial crisis [online]. Available from Internet: http://ssrn.com/abstract=1089926.

Baker, E., et al. 2007. Corporate governance ratings in emerging markets: implications for market valuation, internal firm-performance, dividend payouts and policy. Asian Institute of Corporate Governance.

Bauer, R., et al. 2003. Empirical evidence on corporate governance in Europe. The effect on stock returns, firm value and performance, EFMA 2004 Basel Meetings Paper. SSRN.

http://dx.doi.org/10.2139/ssrn.444543

Baležentis, A.; Balkienè, K. 2014. Innovation policy measurement: analysis of Lithuania's case, Economic Research - Ekonomska Istraživanja 27(1): 1-14.

Bebchuk, L. A.; Cohen, A.; Ferrell, A. 2004. What matters in corporate governance, Discussion Paper No. 491. Harvard Law School, John M. Olin Center.

Black, B. 2001. The corporate governance behavior and market value of Russian firms, Emerging Markets Review 2: 89-108. http://dx.doi.org/10.1016/S1566-0141(01)00012-7

Black, B. S; Khanna, V. S. 2007. Can corporate governance reforms increase firms' market values? Evidence from India, Journal of Empirical Legal Studies 4: 749-96.

http://dx.doi.org/10.1111/j.1740-1461.2007.00106.x

Blair, M. M. 1998. For whom should corporations be run? An economic rationale for stakeholder management, Long Range Planning 31(2): 195-200. http://dx.doi.org/10.1016/S0024-6301(98)00003-X

Bortolotti, B; Beltratti, A. 2006. The nontradable share reform in the chinese stock market: the role of fundamentals, IDEAS Working Papers 2007.131. Fondazione Eni Enrico Mattei.

Brown, L. D.; Caylor, M. L. 2004. Corporate governance and firm performance. SSRN.

http://dx.doi.org/10.2139/ssrn.586423

Bruno, V. G. G.; Claessens, S. 2007. Corporate governance and regulation: can there be too much of a good thing?, Policy Research Working Paper 4140. World Bank.

Cahn, A.; Donald, D. C. 2010. Comparative company law. Cambridge University Press. http://dx.doi.org/10.1017/CBO9780511779909

Chhaochharia, V.; Laeven, L. A. 2007. Corporate governance, norms and practices, Finance Working Paper 165/2007. ECGI.

Chidambaran, N. K., et al. 2008. Corporate governance and firm performance: evidence from large governance changes. SSRN. http://dx.doi.org/10.2139/ssrn.1108497

Chong, A.; Lopez-de-Silanes, F. 2007. Investor protection and corporate governance: firm-level evidence from Latin America. Inter-American Development Bank, Washington, DC.

Clarke, T. 1998. Research on corporate governance, Corporate Governance 6(1): 57-66.

http://dx.doi.org/10.1111/1467-8683.00081

Claessens, S. 2006. Corporate governance and development, World Bank Research Observer 21(1): 91-122. http://dx.doi.org/10.1093/wbro/lkj004

Core, J. E., et al. 2006. Does weak governance cause weak stock returns? An examination of firm operating performance and investors' expectations, Journal of Finance 61(2): 655-87.

http://dx.doi.org/10.1111/j.1540-6261.2006.00851.x

Davies, P. L. 2000. The board of directors: composition, structure, duties and powers, in The Conference on Company Law Reform in OECD Countries: a Comparative Outlook of Current Trends, 7-8 December 2000, Stockholm, Sweden.

De Nicolo, G., et al. 2008. Corporate governance quality: trends and real effects, Journal of Financial Intermediation 17(2): 198-228. http://dx.doi.org/10.1016/j.jfi.2007.10.002 
Demsetz, H. 1983. The structure of ownership and theory of the firm, Journal of Law \& Economics 26: 375-390. http://dx.doi.org/10.1086/467041

Doidge, C., et al. 2007. Why do countries matter so much for corporate governance?, Journal of Financial Economics 86: 1-39. http://dx.doi.org/10.1016/j.jfineco.2006.09.002

Durnev, A.; Fauver, L. 2007. Stealing from thieves: firm governance and performance when states are predatory. Social Science Research Network. http://dx.doi.org/10.2139/ssrn.970969

Durnev, A.; Kim, E. H. 2005. To steal or not to steal: firm attributes, legal environment, and valuation, Journal of Finance 60: 1461-1493. http://dx.doi.org/10.1111/j.1540-6261.2005.00767.x

Ehikioya, B. I. 2009. Corporate governance structure and firm performance in developing economies: evidence from Nigeria, Corporate Governance 9(3): 231-243.

http://dx.doi.org/10.1108/14720700910964307

El Mehdi, I. K. 2007. Empirical evidence on corporate governance and corporate performance in Tunisia, Corporate Governance 15(6): 1429-1441. http://dx.doi.org/10.1111/j.1467-8683.2007.00655.x

Erickson, J., et al. 2005. Board composition and firm value under concentrated ownership: the Canadian evidence, Pacific-Basin Finance Journal 13(4): 387-410.

http://dx.doi.org/10.1016/j.pacfin.2004.11.002

Fama, E. F. 1980. Agency problems and theory of the firm, Journal of Political Economy 88(2): 375-390. http://dx.doi.org/10.1086/260866

Fama, E. F.; Jensen, M. C. 1983. Separation of ownership and control, Journal of Law and Economics 26: 301-325. http://dx.doi.org/10.1086/467037

Ferreira, M.; Laux, P. A. 2007. Corporate governance, idiosyncratic risk, and information flow, Journal of Finance 62(2): 951-90. http://dx.doi.org/10.1111/j.1540-6261.2007.01228.x

Gangone, A. D.; Ganescu, M. G. 2014. Corporate social responsibility in emerging and developing economies in Central and Eastern Europe - a measurement model from the stakeholder theory perspective, Economic Research - Ekonomska Istraživanja 27(1): 539-558.

http://dx.doi.org/10.1080/1331677X.2014.967535

Gawer, J. 2012. Corporate governance scores and long term performance, in 29th International Conference of the French Finance Association, 15-16 May 2012, Strasbourg, France.

http://dx.doi.org/10.2139/ssrn.2084896

Gillan, S., et al. 2006. Tradeoffs in corporate governance: evidence from board structures and charter provisions. SSRN. http://dx.doi.org/10.2139/ssrn.917544

Gompers, P. A.; Ishii, J. L.; Metrick, A. 2003. Corporate governance and equity prices, Quarterly Journal of Economics 118(1): 107-156. http://dx.doi.org/10.1162/00335530360535162

Gokhan Gunay, S. 2008. Corporate Governance Theory - a comparative analysis of stockholder \& stakeholder governance model. Bloomington, NY: iUnivers, Inc.

Gruszczynski, M. 2006. Corporate governance and financial performance of companies in Poland, International Advances in Economic Research 12(2): 251-259.

http://dx.doi.org/10.1007/s11294-006-9007-5

Haniffa, R.; Hudaib, M. 2006. Corporate governance structure and performance of Malaysian listed companies, Journal of Business Finance \& Accounting 33(7-8): 1034-1062.

http://dx.doi.org/10.1111/j.1468-5957.2006.00594.x

IFC. 2011. Corporate governance. Beograd.

Jensen, M. C.; Meckling, W. H. 1976. Theory of the firm: managerial behaviour, agency costs and ownership structure, Journal of Financial Economics 3(4): 305-360.

http://dx.doi.org/10.1016/0304-405X(76)90026-X

Klapper, L. F.; Love, I. 2004. Corporate governance, investor protection, and performance in emerging markets, Journal of Corporate Finance 10: 287-322. http://dx.doi.org/10.1016/S0929-1199(03)00046-4 
Korent, D.; Đunđek, I.; Čalopa Klačmer, M. 2014. Corporate governance practices and firm performance measured by Croatian corporate governance index (CCGI $\left.{ }^{\circledR}\right)$, Economic Research -Ekonomska Istraživanja 27(1): 221-231. http://dx.doi.org/10.1080/1331677X.2014.952109

Kowalewski, O., et al. 2007. Corporate governance and dividend policy in Poland. Social Science Research Network.

http://dx.doi.org/10.2139/ssrn.986111

Kyereboah-Coleman, A. 2007. Corporate governance and firm performance in Africa: a dynamic panel data analysis. Sabanci University, Istanbul, Turkey.

Larcker, D., et al. 2007. Corporate governance, accounting outcomes, and organizational performance, Accounting Review 82(4): 963-1008. http://dx.doi.org/10.2308/accr.2007.82.4.963

Lehn, K., et al. 2006. Governance indexes and valuation: which causes which?, Journal of Corporate Finance 13(5): 907-928. http://dx.doi.org/10.1016/j.jcorpfin.2007.07.002

Leibenstein, H. 1966. Allocative efficiency vs "X-efficiency", American Economic Review 56(3): 392-415.

Letza, S.; Sun, X.; Kirkbride, J. 2004. Shareholding versus stakeholding: a critical review of corporate governance, Corporate Governance: an International Review 12(3): 242-262.

http://dx.doi.org/10.1111/j.1467-8683.2004.00367.x

Levine, R. 1997. Financial development and economic growth: views and agenda, Journal of Economic Literature 35(2): 688-726.

Love, I. 2011. Corporate performance around the world: what we know and what we don't, World Bank Research Observer 26(1): 42-70. http://dx.doi.org/10.1093/wbro/lkp030

MacMillan, K.; Downing, S. 1999. Governance and performance: goodwill hunting, Journal of General Management 24(3): 11-21.

Maurović, L.; Hasić, T. 2014. Reducing agency costs by selecting an appropriate system of corporate governance, Ekonomska Istraživanja - Economic Research (special issue, 1): 225-242.

McKinsey \& Company. 2000. Investor opinion survey on corporate governance [online]. Available from Internet: http://www.oecd.org/corporate/ca/corporategovernanceprinciples/1922101.pdf

Mijoč, J.; Pekanov Star, D.; Mijoč, I. 2014. Investigation of the relationship between contemporary cost management methods and improvement in financial performance, Economic Research - Ekonomska Istraživanja 27(1): 393-413. http://dx.doi.org/10.1080/1331677X.2014.966970

Mills, R. W.; Weinstein, B. 2000. Beyond shareholder value: reconciling the shareholder and stakeholder perspectives, Journal of General Management 25(3): 79-93.

Morck, R.; Wolfenzon, D.; Yeung, B. 2005. Corporate governance, economic entrenchment and growth, Journal of Economic Literature 43(3): 655-720. http://dx.doi.org/10.1257/002205105774431252

Nenova, T., et al. 2005. Control values and corporate law in Brazil, Latin American Business Review 6(3): 1-37. http://dx.doi.org/10.1300/J140v06n03_01

OECD Principles of Corporate Governance. 2004. [Online]. Available from Internet: www.oecd.org

Penger, S.; Černe, M. 2014. Authentic leadership, employees' job satisfaction, and work engagement: a hierarchical linear modelling approach, Economic Research - Ekonomska Istraživanja 27(1): 508-526. http://dx.doi.org/10.1080/1331677X.2014.974340

Pham, P. K., et al. 2007. Corporate governance and alternative performance measures: evidence from Australian firms. SSRN. http://dx.doi.org/10.2139/ssrn.1015985

Pistor, K.; Chenggang, X. 2002. Fiduciary duty in transitional civil law jurisdictions, lessons from the incomplete law theory, Law Working Paper No. 1 [online]. ECGI. Available from Internet: http:// ssrn.com/abstract $=343480$

Plender, J. A. 1998. Giving people a stake in the future, Long Range Planning 31(2): 211-217.

http://dx.doi.org/10.1016/S0024-6301(98)00005-3 
Post, J. E.; Preston, L. E.; Sachs, S. 2002. Redefining the corporation: stakeholder management and organizational wealth. California: Stanford University Press.

Reddy, K., et al. 2008. Corporate governance practices of small cap companies and their financial performance: an empirical study in New Zealand, International Journal of Business Governance and Ethics 4(1): 51-78. http://dx.doi.org/10.1504/IJBGE.2008.017891

Rui, O. M., et al. 2002. Simultaneous relationships among ownership, corporate governance, and financial performance. Social Science Research Network. http://dx.doi.org/10.2139/ssrn.337860

Schmidt, K. 1997. Gesellschaftsrecht. $3^{\text {rd }}$ ed. Koln: Carl Heymanns Verlag.

Shleifer, A.; Vishny, R. W. 1997. A survey of corporate governance, The Journal of Finance 52: 737-783. http://dx.doi.org/10.1111/j.1540-6261.1997.tb04820.x

Škare, M.; Golja, T. 2014. The impact of government CSR supporting policies on economic growth, Journal of Policy Modeling 36(3): 562-577. http://dx.doi.org/10.1016/j.jpolmod.2014.01.008

The Companies Act. 2006. [Online]. Available from Internet: http://www.legislation.gov.uk/ukpga/2006/46/contents

The Cadbury's Code. 1992. [Online]. Available from Internet: http://www.ecgi.org/codes/documents/ cadbury.pdf

Toudas, K; Karathanassis, G. 2007. Corporate governance and firm performance: results from Greek firms. Social Science Research Network. http://dx.doi.org/10.2139/ssrn.1067504

Verbič, M.; Polanec, S. 2014. Innovativeness and intangibles in transition: the case of Slovenia, Economic Research - Ekonomska Istraživanja 27(1): 67-85.

http://dx.doi.org/10.1080/1331677X.2014.947109

Yen, S.-W. 2005. Are well governed firms safe investments? Social Science Research Network. http://dx.doi.org/10.2139/ssrn.648401

Zheka, V. 2006. Does corporate governance causally predict firm performance? Panel data and instrumental variables evidence, CERT Discussion Paper No. DP06/05. SSRN.

http://dx.doi.org/10.2139/ssrn.877913

Marinko ŠKARE. Professor of Economics, Economic Research Journal Editor in Chief, Member of Editorial Board of several international journals, Department Economics and Tourism "Dr. Mijo Mirković" in Pula, Juraj Dobrila University of Pula. He served as Assistant Dean for Education, Faculty of Economics \&Tourism, Pula, Assistant Dean for International Cooperation, Faculty of Economics \& Tourism, Pula, Main and Team Researcher on several scientific projects, Former Dean of the Faculty of Economics \& Tourism, Pula and Former Vice President for International Cooperation, Juraj Dobrila University of Pula. He has published several books and a large number of scientific papers on the subject of economic growth, welfare economics and poverty, human capital, economics in transition, economic philosophy and monetary economics. He is a member of the American Economic Association, Royal Economic Society, Economic History Association, Economic History Society, and Association for Comparative Economic Studies.

Tea HASIĆ. She received a Magistra Iuris degree at University of Rijeka, School of Law and currently is postgraduate student and $\mathrm{PhD}$ candidate at University of Zagreb, School of Law - postgraduate doctoral study: commercial and company law. She is a Research Assistant at Juraj Dobrila University of Pula, Faculty of Economics and Tourism (Pula).

She is a member of research team on Megasfora (Modelling Economic Growth - Advanced Sequencing Algorithm) project. Her scientific and research interests are: Company Law, EU Company Law, Corporate Governance - especially the rule of shareholders in corporate governance. 